Chapman University

Chapman University Digital Commons

English Faculty Books and Book Chapters

English

$9-2015$

\title{
Community Colleges and First-Generation Students: Academic Discourse in the Writing Classroom
}

Jan Osborn

Chapman University, josborn@chapman.edu

Follow this and additional works at: https://digitalcommons.chapman.edu/english_books

Part of the Bilingual, Multilingual, and Multicultural Education Commons, Community College Leadership Commons, Ethnic Studies Commons, Other Education Commons, and the Reading and Language Commons

\section{Recommended Citation}

Osborn, Jan. Community Colleges and First-Generation Students: Academic Discourse in the Writing Classroom. New York: Palgrave Macmillan, 2015.

This Book is brought to you for free and open access by the English at Chapman University Digital Commons. It has been accepted for inclusion in English Faculty Books and Book Chapters by an authorized administrator of Chapman University Digital Commons. For more information, please contact laughtin@chapman.edu. 


\section{CHAPTER 2}

\section{Identities: A Context of Multiplicity}

In Dreams from My Father, Barack Obama tells the story of his search for identity: a social, cultural, linguistic journey of discovery. While visiting his father's family in Kenya, he and his half-sister Auma leave a restaurant where they are ignored while the black waiter serves white patrons. Obama (2004) reflects upon the life that has generated the waiter's actions, wondering if the waiter realizes he is "serving the interests of neocolonialism," or if he "straddles two worlds, uncertain in each, always off balance" (p. 315). Obama links the man's confusion to that of his father and grandfather, to his own confusion. Later, standing at their graves, he is able to understand how they had to reinvent themselves, how they, too, were confused. His father, for example, traveling to the United States,

$[w]$ ith the degree, the ascot, the American wife, the words, the figures, the wallet, the proper proportion of tonic to gin, the polish, the panache, the entire thing seamless and natural ... He had almost succeeded, in a way his father could never have hoped for. And then, after seeming to travel so far, to discover that he had not escaped at all. ( $p$. 428)

Obama sweeps his hand across his father's grave, assuring him that there was no shame in his confusion, no shame in his father's confusion, only shame in the silence the fear and confusion produced. "It was the silence that betrayed us," he says, the silence that kept father from telling son "that he could never escape himself" (p. 429). 
On January 20, 2009, Barack Hussein Obama became the 44th president of the United States of America. In his first inaugural address, Obama (2009) acknowledged his identity as an African-American, describing the coming together of many identities as a strength of the nation, citing diversity of religion and language and culture- "For we know that our patchwork heritage is a strength, not a weakness" - evoking ideas that have been central to our sense of ourselves since the beginning of the republic.

President Obama (2013) evoked this grand narrative in his second inaugural address as well, focusing on immigration and equal opportunity:

Our journey is not complete until we find a better way to welcome the striving, hopeful immigrants who still see America as a land of opportunity, until bright young students and engineers are enlisted in our workforce rather than expelled from our country.

These words of opportunity, of equal access to education and employment are linked in our national rhetoric. As President Obama (2013) said in that second inaugural,

[W]e bear witness to the enduring strength of our Constitution. We affirm the promise of our democracy. We recall that what binds this nation together is not the colors of our skin or the tenets of our faith or the origins of our names.

Yet Joseph Stiglitz (2013), Nobel laureate in economic sciences, says a "gap between aspiration and reality could hardly be wider." The promise of our democracy is being stretched thin in our education system. The question becomes whether we embrace this rhetoric of diversity in terms of policy, particularly educational policy, or not. We simply cannot keep silent 
about this gap between aspiration and reality, for, as Obama discovered in his own journey, it is silence that will betray us.

Do we, in fact, ask our linguistically diverse students to escape themselves to achieve in the education arena, creating a gap between their aspiration and reality? Do we "know that our patchwork heritage is a strength," as our national rhetoric asserts? I do not see such knowledge played out in our educational institutions, or our education policies. If we, indeed, accept that we are "shaped by every language and culture, drawn from every end of this Earth," we would then acknowledge and accept an integration of social, cultural, and linguistic diversities, embracing diversity in more nuanced ways, conceptualizing an America through a lens of plurality. We would, then, genuinely accept "our patchwork heritage" as a strength rather than attempt to assimilate difference out of the concept.

A national need for more skilled labor from a pool of immigrants may engender policies that create genuine opportunities for all, or it may engender an increased vigilance against diversity, indicating the threatened majority trying to shore up its dominance. With the demographics of the country changing, questions of identity abound. Who is an American? What will happen to America if we do not assimilate students through education? What is education if not an assimilative process? While these are certainly not new questions, they continue to impact educational choices. Can the demographic changes be precursors to a multiplicity that will, in turn, change the discourse of diversity? Are we developing a more organic understanding of identity as plural, a process of identities? A process of diversities? Young (2008) suggests that diversity is a term "at the very least vexed and at worst meaningless or even damaging since for many it has become an empty signifier often employed to suggest progress on one hand or to invoke anxiety or outrage on the other" (par. 3). Certainly the changing landscape requires that 
we consider diversity in more nuanced and complex ways, "challenge[ing] the stability of social relations and systems of power that have defined diversity only as certain fixed categories of identity" (Young, 2008, par. 5). Dingo (2008) uses the term transnationalism to "refer to how globalism has influenced the movement of people and the production of texts, culture, and knowledge across borders" (par. 3); like Young, Dingo argues that the relationship between diversities and identities must be "troubled" (par. 2). The sociologist Manuel Castells (2000) affirms this need to investigate identity: "In a world of global flows of wealth, power, and images, the search for identity—collective or individual, ascribed or constructed—becomes the fundamental source of social meaning" (p. 3). And this meaning making, this search for identity, is languaged in a dominant culture in the United States that often attempts to erase language differences (Lu \& Horner, 2013, p. 583). Lin (2008) cautions that the notion of identity is not benign, for those with power have an advantage in "constructing for themselves advantageous identities" and controlling "the identity game" (p. 1) for those in subordinate positions. As more students from diverse backgrounds attend community colleges, their linguistic heterogeneity is of prime importance. Lu and Horner (2013) point to "the ongoing pluralization of English into more and more world 'Englishes'; the explosion of cross-language communication accompanying changes in global migration patterns and global communication technologies; and the permeability of linguistic boundaries" (p. 582). These factors materialize in community college classrooms.

Diversity is not fixed; in fact, it is ever evolving, as are one's identities and languages. We live in a hybridized reality and can no longer treat "languages as discrete, stable, internally uniform, and linked indelibly to what is held to be each [student's] ... stable and uniform location and social identity" (Lu \& Horner, 2013, p. 583). Education, in a new transnational 
reality, increasingly serves students with a range of diversities, so we must consider how educators frame the discourse of diversity, how we socially construct the diversities the students embody as they extend their postsecondary educational journey.

This study, conducted in a writing class in an urban community college serving students from diverse social, cultural, and language backgrounds, asks how the community college setting itself constructs how the students are perceived by their instructors. How does the community college classroom address the diversities the students embody? And on yet another level, how does an academic writing classroom at the community college construct how the students are to write/sound? How do community college writing instructors "hear" the voices of writers from diverse backgrounds? How is academic language socially constructed—or reconstructed—in light of student diversities? How do the students negotiate their diversities in the space created between a socially constructed idea about their diversity and a socially constructed idea about academic writing? Is it possible, in a world of global flows, to create spaces where diversities may no longer be sources of confusion, of shame, of silence?

Mike Rose's classic Lives on the Boundary (1989) argues that college writing classes function as an initiation or testing ground for students who want to achieve the role of college student. Herzberg (1991) furthers Rose's "initiation or testing ground" metaphor: "the ability to use academic discourse is crucial to the success of 'nontraditional' students" and that "freshman composition frequently serves as a curricular screen to filter out unprepared students” (p. 99). Because community colleges serve the majority of students from diverse backgrounds, what occurs in community college writing classrooms is of tremendous importance if all students are to be provided access to academic discourse and an opportunity for higher education. 
Certainly, if community colleges continue to be the dominant form of higher education for socially, culturally, and linguistically diverse students and if community college writing courses continue to be critical gatekeepers, research in this area is vital. Shor (2001) encourages such research with a reminder that "these bustling sites of student hope and teacher devotion are too invisible, misrepresented, and dismissed" (p. 133). He highlights the need to raise the profile on the "enormous writing enterprise underway there, the invisible 'other' of academe" (p. 133), the community college. Over a decade later, this call for a closer look must be heeded, especially as a free community college initiative will, most likely, go before Congress this year.

Sociocultural perspectives on writing provide theoretical insight into why the writing course often serves as a critical gatekeeper for community college students. These perspectives look at the writer-in-context, noting how writing is situated in larger discourse activities in multiple contexts of social, cultural, and linguistic realities (Lin, 2008; Smagorinsky, 2006; Sperling \& Freedman, 2001; Vandenberg, Hum, \& Clary-Lemon, 2006). Markers of identity, such as race/ethnicity, class, and language, affect the way students view themselves as they confront discourses - ways of talking and writing — that legitimize and value some identities more than others (Pavlenko \& Blackledge, 2004). Moore (2006) explains how particular identities may be viewed through a deficit lens, with first-generation, minority, and lower socioeconomic students in the community college often considered "academic outcasts in higher education" (p. 145). Micciche's (2014) discussion of new materialism complicates the social turn, with its focus on textual and linguistic analysis and ideology critique, in a "transdisciplinary effort to ... reckon with a much-expanded notion of agency" (p. 489). While the scope of this project does not employ the full range of new materialism, it does embrace the notion that "[a]gency is distributed across things and people and structures" (Micciche, 2014, p. 490), 
resulting in a "more robust accounting of the interstitial qualities" (p. 491) of the problem at hand. The social turn shifted the focus from the individual writer to a fuller understanding of context, including institutional, cultural, and political realities. Micciche explains writing in the new materialism configuration as a process of "curating materials to create narrative, identity, community, or other significant meanings" (UCLA Mellon seminar (2011) as cited in Micciche, 2014, p. 494). This challenges the individual/community binary, making writing a much more “distributed act" (p. 494).

Of particular value to this study is Kathleen Stewart's (2007) work with agency. For Stewart, agency is diffuse and unstable. Her metaphor of agency as both finding and losing self is particularly relevant:

[A]ction is always a reaction; that the potential to act always includes the potential to be acted upon, or to submit; that the move to gather a self to act is also a move to lose the self; that one choice precludes others; that actions can have unintended and disastrous consequences; and that all agency is frustrated and unstable and attracted to the potential in things. (p. 86)

As the focus for higher education turns to the community college, we must consider this finding and losing of self, we must consider the potential of our community college students and what "unintended and disastrous consequences" might there be if we do not understand how classroom discourse works to establish identities. 